\title{
Discrimination Against Vulnerable Groups in Exercising Their Voting Rights Due to Systemic Flaws in the Macedonian Electoral Legislation ${ }^{1}$
}

\author{
Jelena Ristic, PhD \\ Assistant Professor, School of Law, \\ University American College Skopje, North Macedonia
}

URL:http://dx.doi.org/10.19044/esj.2020.v16n23p10

\begin{abstract}
Various credible reports show that the Republic of North Macedonia has achieved a good level of democracy in terms of election and voting. However, there are still areas where improvements can be done in order to strengthen the constitutional right to vote of various groups of citizens. These groups of citizens include certain vulnerable groups, such as persons placed in facilities for care of the elderly and public health facilities for the treatment of mental illness, who seem to be placed in a less favourable position compared to other citizens. In this sense, the paper has placed its focus on analysis of certain systemic flaws within the Electoral Code and the effect they have on the voters placed in facilities for care of the elderly and public health facilities for the treatment of mental illness, especially in terms of discrimination against these vulnerable groups. Finally, conclusions will be drawn in order to contribute to the improvement of the protection of the constitutional right to vote of these vulnerable groups.
\end{abstract}

Keywords: Right to vote, elections, discrimination, vulnerable groups, North Macedonia

\section{Introduction}

The right to vote is one of the fundamental preconditions for the rule of law and the practice of democracy in a modern state. Namely, the respect of the free voting right provides for legitimacy and legality of the government,

${ }^{1}$ This paper has its genesis in a research conducted by the author, within the project "Legal Protection of Voting Rights", implemented by the Institute for Legal and Political Research and funded by the U.S. Embassy Skopje and the Embassy of the Kingdom of the Netherlands Skopje, which led to the publication of the author of this paper, Legal Protection of Voting Rights: Challenges and Perspectives, 2019 
while the elections, in general, reflect the current level of democracy achieved in a particular society.

The legal framework that provides mechanisms for protection of the voting rights plays a key role in ensuring free and fair elections. In most countries, including the Republic of North Macedonia, the main mechanisms for protection of the voting rights are directed towards the election administration and the courts.

It is evident from the latest credible reports, such as the OSCE/ODIHR Election Observation Mission Reports (OSCE/ODIHIR, 2019; OSCE/ODIHIR, 2019a; OSCE/ODIHIR, 2018; OSCE/ODIHIR, 2017), that the Republic of North Macedonia has achieved progress in the last years concerning the protection of the right to vote and securing free and fair elections, and that it has a good level of democracy in that sense. However, it seems that there is still space for improvement in this area, including the election legislation.

Namely, it seems that there are certain systemic flaws within the Electoral Code, which have a potential to prevent certain groups of citizens that from exercising their constitutional right to vote (Ristikj, 2019). These groups of citizens include persons who belong to various vulnerable groups, such as persons placed in facilities for care of the elderly and public health facilities for the treatment of mental illness. Moreover, it also seems that the previously mentioned systemic flaws might lead to discrimination against these vulnerable groups of citizens by placing them in a less favorable position compared to other citizens.

The main focus of this paper is put on locating potential systemic flaws within the Electoral Code, and analysis of the effect they might have on voters placed in facilities for care of the elderly and public health facilities for the treatment of mental illness, in terms of exercising their voting rights. In this regard, a special focus will placed on the issue of possible discrimination against these vulnerable groups.

This will be done through review and analysis of the relevant national and international legal framework, and various documents and letters issued by the State Election Commission concerning the Municipal elections in 2017, the Referendum in 2018 and the Presidential elections in 2019. Finally, the results of the analysis conducted will be summarised. The paper aims to contribute to enhancing the protection of the individual right to vote of vulnerable groups, as well as the protection of the right to vote in general.

\section{Relevant Legal Framework}

The protection of the voting rights is primarily regulated by the Constitution of the Republic of North Macedonia and the Electoral Code, but also by other laws. Moreover, Republic of North Macedonia is a party to 
various key international and regional instruments relevant to the protection of the voting rights, which provides an additional guarantee that the legal framework related to voting rights is sufficient to ensure a solid level of protection in this regard (Ristikj, 2019, p.13).

\section{National legal framework}

The basis for legal protection of the voting rights in the Republic of North Macedonia is clearly determined in the Constitution of the Republic of North Macedonia. Namely, Article 22 of the Constitution stipulates that: "Every citizen who has reached the age of 18 shall have a voting right. The voting right is equal, universal and direct and is exercised in free elections by secret ballot. Persons who have been deprived of their mental capacity shall not have a voting right." Moreover, Article 9 of the Constitution states: "Citizens of the Republic of North Macedonia are equal in their freedoms and rights irrespective of gender, race, colour, national and social origin, political and religious beliefs, property and social status. Citizens are equal before the Constitution and laws".

The Electoral Code makes no distinction as to the type of elections. Namely, the same law applies to all types of elections and the problems that arise automatically relate to the right of the citizens to vote at all levels. However, specific types of elections also have their own specificities.

The Electoral Code states in Article 6 that "A right to vote is granted to every citizen of the Republic of Macedonia who has reached 18 years of age and has a mental capacity, and has a permanent residence in the election unit, municipality, or city of Skopje where the election is being made."

Article 111 of the Electoral Code regulates the voting of a disabled person or a sick person, according to which the manner and conditions for voting of a disabled or sick person are determined. Namely, the Electoral Code determines the manner in which disabled and sick persons, i.e. persons who are not able to vote at the polling station, can exercise their right to vote. In paragraph 1 of Article 111, the Electoral Code provides that the voter who is not able to vote at the polling station (infirm or sick person according to the instructions issued by the State Election Commission), and wishes to vote, shall inform the municipal election commission, or the Election commission of the City of Skopje seven days at the latest before the day designated for voting. Subject to paragraph 4 of this Article, the electoral board shall enable the person referred to in paragraph 1 of this Article to vote in his or her home one day before the election, in a manner that ensures the secrecy of the vote. Paragraph 5 of the same Article stipulates that the electoral board for the voting referred to in paragraph 4 of this Article provides a special ballot box that is brought empty in the home where the voter is. In accordance with 
paragraph 6, the voting referred to in paragraph 4 of this Article shall be recorded by the electoral board in the minutes.

With regard to persons serving prison sentences or have been remanded in custody or placed under house arrest, the Electoral Code in Article 113 provides that "Voters who serve prison sentences or have been remanded in custody or placed under house arrest on election day shall vote in the penitentiary facilities or the place where they are held under house arrest measure.

The Law on Referendum and Other Forms of Direct Citizens' Vote in Article 7 provides that: "At the referendum citizens shall vote directly by secret ballot. A right to vote at referendum is granted to citizens who have voting right and are registered in the Voter list".

In addition, Article 45 of the Law on Referendum and Other Forms of Direct Citizens' Vote should be taken into consideration, according to which "The provisions of the Law on Election of Members of Parliament of the Republic of Macedonia shall be applied when conducting a referendum at the state level, if is not otherwise determined in this law ", as well as Article 1 of the Electoral Code, according to which "This Code regulates the manner, conditions and procedure for election of President of the Republic of Macedonia ...., for election of Members of Parliament of the Republic of Macedonia. ...".

Namely, on the day of entry into force of the Electoral Code, the Law on Election of Members of Parliament of the Republic of Macedonia ceases to be valid, i.e. the manner, conditions, and procedure for electing Members of the Assembly of the Republic of Macedonia shall be regulated by the provisions of the Electoral Code.

There are also other laws that can be significant in terms of legal protection of the voting right, although they do not explicitly provide protection of this right. One of those laws is the Law on Prevention and Protection against Discrimination.

Article 5 of the Law on Prevention and Protection against Discrimination prohibits "any discrimination based on race, skin colour, origin, national or ethnic affiliation, sex, gender, sexual orientation, gender identity, belonging to a marginalized group, language, citizenship, social origin, education, religion or belief, political belief, other belief, disability, age, family or marital status, property status, health status, personal status and social status or any other basis (hereinafter: discriminatory basis)".

With regard to the definition of direct discrimination, Article 8 paragraph 1 of the Law on Prevention and Protection against Discrimination provides that "direct discrimination exists when one person or group is treated, was treated or would be treated less favourably than another person or a group 
in a factual or possible comparable or similar situation, on a discriminatory basis".

\section{International legal framework}

The legal protection of the voting right is also enshrined in international law, starting with the Universal Declaration of Human Rights as the first comprehensive international human rights document and the foundation of international human rights protection.

According to Article 21 of the Universal Declaration of Human Rights, "Everyone has the right to take part in the government of his country, directly or through freely chosen representatives".

Further, Article 25 of the International Covenant on Civil and Political Rights foresees: "Every citizen has the right and opportunity, without any discrimination and without undue limitation: to participate in the management of public affairs, either directly or through freely elected representatives; to elect and to be elected in periodic, authentic, general, equal and secret elections, which ensure the free expression of the will of the electorate".

According to Article 29 of the Convention on the Rights of Persons with Disabilities, "States Parties shall guarantee to persons with disabilities the political rights and the opportunity to enjoy them on an equal basis with others, and shall undertake to: ensure that persons with disabilities can effectively and fully participate in political and public life on an equal basis with others, directly or through freely chosen representatives, including the right and opportunity for persons with disabilities to vote and be elected, inter alia, by: Ensuring that voting procedures, facilities and materials are appropriate, accessible and easy to understand and use".

Article 3 of Protocol 1 to the European Convention on Human Rights guarantees the right to free elections. Namely, this provision provides that "The High Contracting Parties undertake to hold free elections at reasonable intervals by secret ballot, under conditions which will ensure the free expression of the opinion of the people in the choice of the legislature".

Article 14 of the European Convention on Human Rights provides for a prohibition of discrimination in respect of the rights protected by the Convention: "The enjoyment of the rights and freedoms set forth in this Convention shall be secured without discrimination on any ground such as sex, race, colour, language, religion, political or other opinion, national or social origin, association with a national minority, property, birth or other status".

Article 1 of Protocol 12 to the European Convention on Human Rights provides for a general prohibition on discrimination: "The enjoyment of any right set forth by law shall be secured without discrimination on any ground such as sex, race, colour, language, religion, political or other opinion, national 
or social origin, association with a national minority, property, birth or other status".

Further, paragraph 7.3 of the OSCE Copenhagen Document obliges member states to "guarantee universal and equal suffrage to adult citizens" in order, according to paragraph 7, "to ensure that the will of the people is used as a basis for government authority".

In addition to the abovementioned international documents, provisions relevant to the protection of the right to vote are contained in the Venice Commission Code of Good Practice, the EU Charter of Fundamental Rights, several resolutions, recommendations and declarations of the Council of Europe, OSCE and UN, and other documents.

\section{Voters in Facilities for Care of the Elderly and Public Health Facilities for the Treatment of Mental Illness}

In response to a request for access to public information submitted to the State Election Commission by the Institute for Legal and Political Research $^{2}$, as regards the number of persons placed in homes for care of the elderly who have exercised their right to vote at the Municipal elections in 2017, the Referendum in 2018 and the Presidential elections in 2019, the State Election Commission informed that, according to the Electoral Code, voting is not foreseen in the homes for care of the elderly and thus it cannot be organized in these facilities. In addition, it emphasized that the voters that are infirm or sick, according to the Article 111 of the Electoral Code, exercise their right to vote at their home (State Election Commission, 2017; 2018; 2018a; 2019a).

In this regard, it is noteworthy that during the Presidential elections held in 2019, for the first time, a pilot project was carried out on the right to vote by persons placed in two homes for care of the elderly (State Election Commission, 2019, p.5). In this way, the citizens placed in these two facilities have been provided an opportunity to exercise their right to vote even though the Electoral Code did not contain specific provisions in this sense.

Furthermore, in response to a request for access to public information submitted to the State Election Commission by the Institute for Legal and Political Research ${ }^{3}$, concerning the number of persons placed in public health facilities for the treatment of mental illness by a court decision (not deprived of their mental capacity) who exercised their right to vote at the Municipal elections in 2017, the Referendum in 2018 and the Presidential elections in 2019, the State Election Commission informed that according to the Electoral

\footnotetext{
${ }^{2}$ https://ippi.mk/

${ }^{3}$ Ibid.
} 
Code voting is not foreseen in such facilities and thus it cannot be organized in these facilities (State Election Commission, 2017a; 2018b; 2019b).

Consequently, persons who were temporarily cared for in institutions for care of the elderly and the public health institutions for the treatment of mental illness could not exercise their right to vote during the respective elections. Among the other, this is also due to the fact that the State Election Commission, according to the information delivered in response to the abovementioned requests for access to public information, disregarded the conditions set by the Constitution of the Republic of North Macedonia in its Article 22 and established an additional condition for these persons, which is not provided for in Article 111 of the Electoral Code. Namely, paragraph 1 of Article 111 of the Electoral Code provides that "the voter who is not able to vote at the polling station (infirm or sick person according to the instructions issued by the State Elections Commission), and wishes to vote, shall inform the Municipal election commission, or the Election commission of the City of Skopje seven days at the latest before the day designated for voting". In paragraph 4 of Article 111 it is foreseen that "the electoral board shall enable the person referred to in paragraph 1 of this Article to vote in his or her home one day before the election, in a manner that ensures the secrecy of the vote", while Paragraph 5 of the same Article stipulates that "the electoral board for the voting referred to in paragraph 4 of this Article provides a special ballot box that is brought empty in the home where the voter is".

It is evident that the State Election Commission has a very restrictive interpretation of the term "home". It only considers as "home" the address stated in the ID card, although the homes for care of the elderly and the public health institutions for the treatment of mental illness cannot be registered as a residence in the ID card of the citizens that are placed there, which results in a violation of the constitutionally guaranteed right to vote provided by Article 22 of the Constitution of the Republic of North Macedonia.

Namely, this is due to the fact that the State Election Commission, contrary to Article 22 of the Constitution of the Republic of North Macedonia, as well as Article 6 of the Electoral Code, established a rather restrictive opinion on what is understood under the term "home", and therefore did not provide for voting in long-term care homes where elderly and disabled persons live, or in the public health institutions for the treatment of mental illness. However, according to the European Court of Human Rights, the term "home" is identified as "the place where the person lives on permanent basis or with which the person has sufficient and continuous links" (Roagna, 2012, p.30).

Despite the fact that the Electoral Code provides the broad term "home", the State Election Commission does not take action in the direction of providing conditions for enjoying the right to vote in the manner defined in Article 22 of the Constitution of the Republic of North Macedonia. On the 
contrary, it moves toward reducing the possibility of exercising of this right. Defining the term "home" as the residence registered in a citizen's ID card in this case is restrictive, as it turns out it prevents at least two groups of people from enjoying their right to vote.

The first group are the persons who are accommodated in homes for care of the elderly, and despite staying there, have not changed their address in the ID card. The second group are the persons who are placed in public health facilities for the treatment of mental illness by a court decision, but who have not been deprived of their mental capacity. This group cannot change their address in the ID card as well. Both groups can be considered to be infirm and sick persons, but due to the fact that they are placed in these facilities and thus are not able to vote in their place of residence, i.e. the address stated in the ID card, their right to vote has been denied.

The State Election Commission put these two groups in an unequal position compared to the group of persons who are also infirm and sick, but because they live in their homes (registered in their ID cards), they can exercise their right to vote. Namely, the persons placed in homes for care of the elderly and public health facilities for the treatment of mental illness faced a direct discrimination due to the fact that they are put in a less favourable position compared to other infirm and sick persons, who were in their homes as registered in their IDs on the election day, where they could vote in accordance with Article 111 of the Electoral Code.

Moreover, these persons are also placed in a less favourable position compared to persons serving a prison sentence who have not changed their residential address as well, but this fact is not a reason to restrict their right to vote, as foreseen by Article 113 of the Electoral Code.

In this manner, the persons placed in homes for care of the elderly and public health facilities for the treatment of mental illness have been prevented from voting and discriminated against in terms of exercising their voting rights guaranteed by the Constitution and the international agreements ratified by the Republic of North Macedonia, despite the fact that they fulfilled the necessary conditions in that regard.

This situation is also noted by the OSCE/ODIHR Election Observation Mission in one of its reports as regards the Municipal elections in 2017, where it is established that "as there are no provisions to accommodate voters in hospitals, long-term care facilities and retirement homes, those voters were also disenfranchised (OSCE/ODIHR, 2017a, p.4).

In addition, the unequal treatment was also stated by the Ombudsman in the Annual Report on the Work of the Ombudsman for 2016, which for the early parliamentary elections states that "discrimination against this category of persons arises from the fact that without any objective circumstances of the SEC they are not allowed to vote in places where they stay for a long time or 
permanently - nursing homes and the like, gerontological institutions, hospitals and other medical facilities" (Ombudsman of the Republic of North Macedonia, 2017, p.42).

Furthermore, the unequal treatment has also been noted by the Ombudsman in several annual reports. Thus, in the Annual Report on the Work of the Ombudsman for 2017, it is established that, during the Municipal elections held in 2017, the State Election Commission had manifested unequal, i.e. discriminatory treatment in relation to the category of infirm or sick persons, as it did not provide their inclusive coverage in the sense to provide for all persons that belong to this category the opportunity to vote at the place where they reside. In this regard, it was noted that the persons placed in homes for the elderly, rehabilitation centres, mental facilities and similar institutions, or who are placed for long-term treatment in hospitals and other health institutions are completely prevented to vote at the places where they are residing (Ombudsman of the Republic of North Macedonia, 2018, p.39).

In the Annual Report on the Work of the Ombudsman for 2018, it is recommended "in the direction of equal treatment and protection against discrimination on any grounds provided by law, to take appropriate measures from a normative and technical point of view to remove all restrictions and adjusting the infrastructure and the space for the blind, the visually impaired, the physically disabled, as well as the sick and infirm, so that they can exercise their right to vote" (Ombudsman of the Republic of North Macedonia, 2019, p.89-91).

Having in mind the relevant provisions in the abovementioned international instruments, the state has an obligation to interpret the right to vote as extensively as possible and to create all the conditions for each person to actually practice this right. This is also the position of the European Court of Human Rights. Namely, the Court found that "the right to vote is not a privilege ... the presumption in a democratic State must be in favour of inclusion" (Hirst v. the United Kingdom (no. 2) [GC], 2005, § 59). Moreover, the Court noted that "any departure from the principle of universal suffrage risks undermining the democratic validity of the legislature thus elected and the laws it promulgates" (Hirst v. the United Kingdom (no. 2) [GC], 2005, § $62)$.

Furthermore, as to the right not to be discriminated, the European Court of Human Rights held that this right is violated "when States treat differently persons in analogous situations without providing an objective and reasonable justification", as well as in case "when States without an objective and reasonable justification fail to treat differently persons whose situations are significantly different" (Thlimmenos v. Greece [GC], 2000, § 44). ${ }^{4}$

\footnotetext{
${ }^{4}$ Similar: Pretty v. the United Kingdom, no. 2346/02, § 88, ECHR 2002-III
} 


\section{Conclusion}

During the Municipal elections held in 2017, the Referendum held in 2018 and the Presidential elections held in 2019, the persons placed in placed in homes for care of the elderly and public health facilities for the treatment of mental illness were prevented from exercising their constitutional right to vote. This is mainly due to the lack of provisions in this regard in the Electoral Code, but it is also due to the established practice of the State Election Commission for restrictive interpretation of the term "home". Namely, these voters could not vote under Article 111 of the Electoral Code because they are not in their home-the term "home" being defined according to the State Election Commission, in the sense that they are not at the home determined as their residence according to their ID.

These two groups of citizens have not changed their address of residence and fulfil all conditions necessary to be eligible to exercise the right to vote, but they cannot vote only due to the fact that on election day they are placed in a home for care of the elderly or in a public health facility for the treatment of mental illness. In this manner, these persons are put in a less favourable position compared to the other infirm and sick persons, who are in the home determined according to their ID and who voted in accordance with Article 111 of the Electoral Code.

As a result, the persons placed in homes for care of the elderly and public health facilities for the treatment of mental illness faced a direct discrimination based on personal status and health condition, which prevented them from the opportunity to exercise their voting rights, although they fulfil the conditions for their enjoyment. The direct discrimination resulted from the lack of provisions in the Electoral Code as regards voting in facilities for care of the elderly and public health facilities for the treatment of mental illness, as well as from the interpretation of the State Election Commission. In this sense, the State Election Commission violated Article 9 of the Constitution of the Republic of North Macedonia, Article 8 of the Law on Prevention and Protection against Discrimination and Article 1 of Protocol 12 of the European Convention on Human Rights in conjunction with Article 22 of the Constitution of the Republic of North Macedonia.

A positive development in this context took place during the Presidential elections held in 2019, when, for the first time, a pilot project was carried out on the right to vote by persons placed in two homes for care of the elderly. The voting was organized in the two facilities for the citizens placed in them to be provided an opportunity to exercise their right to vote. However, the Electoral Code remained unchanged in that regard.

It could be concluded from the elaboration above that it is a priority to make appropriate amendments to the legal framework, mainly in regard to the Electoral Code, aiming to correct the systemic weaknesses that produce 
citizens who cannot exercise their constitutional right to vote. Namely, having in mind the foregoing, the amendments of the Electoral Code should include specific provisions that provide for persons placed in homes for care of the elderly and public health facilities for the treatment of mental illness, who are entitled to vote, to be able to exercise their voting rights.

\section{References:}

1. Assembly of the Republic of North Macedonia. (1991; 1992; 1998; $2001 ; 2003 ; 2005 ; 2009 ; 2011 ; 2019)$. Constitution of the Republic of North Macedonia. Official Gazette of the Republic of Macedonia, No. 52/1991; 1/1992; 31/1998; 91/2001; 84/2003; 107/2005; 03/2009; 49/2011; 6/2019

2. Assembly of the Republic of North Macedonia. (2005). Law on Referendum and Other Forms of Direct Citizens' Vote. Official Gazette of the Republic of Macedonia, No. 81/2005

3. Assembly of the Republic of North Macedonia. (2006; 2008; 2011; 2012; 2013; 2014; 2015; 2016; 2017; 2018; 2019). Electoral Code. Official Gazette of the Republic of Macedonia, No. 40/2006; 136/2008; 148/2008; 155/2008; 163/2008; 44/2011; 51/2011; 54/2011; $142 / 2012 ; 31 / 2013 ; 34 / 2013 ; 14 / 2014 ; 30 / 2014 ; 196 / 2015 ; 35 / 2016$; 97/2016; 99/2016; 136/2016; 142/2016; 67/2017; 125/2017; 38/2018; 99/2018; 140/2018; 208/2018; 27/2019

4. Assembly of the Republic of North Macedonia. (2019). Law on Prevention and Protection against Discrimination. Official Gazette of the Republic of North Macedonia, No. 101/2019

5. Council of Europe. (1950). Convention for the Protection of Human Rights and Fundamental Freedoms, as amended by Protocols Nos.11 and 14, supplemented by Protocols 1, 4, 6, 7, 12 and 13, European Treaty Series, No.5

6. Council of Europe. (2000). Protocol 12 to the Convention for the Protection of Human Rights and Fundamental Freedoms, European Treaty Series, No.177

7. European Court of Human Rights - judgments:

-Hirst v. the United Kingdom (no. 2) [GC], no. 74025/01, § 59, ECHR 2005-IX

-Thlimmenos v. Greece [GC], no. 34369/97, § 44, ECHR 2000-IV;

-Pretty v. the United Kingdom, no. 2346/02, § 88, ECHR 2002-III

8. Ombudsman of the Republic of North Macedonia. (2019). Annual Report on the Level of Securing Respect, Promotion and Protection of Human Freedoms and Rights for 2018, Skopje: Ombudsman of the Republic of North Macedonia 
9. Ombudsman of the Republic of North Macedonia. (2018). Annual Report on the Level of Securing Respect, Promotion and Protection of Human Freedoms and Rights for 2017, Skopje: Ombudsman of the Republic of North Macedonia

10. Ombudsman of the Republic of North Macedonia. (2017). Annual Report on the Level of Securing Respect, Promotion and Protection of Human Freedoms and Rights for 2016, Skopje: Ombudsman of the Republic of North Macedonia

11. OSCE/ODIHR Election Observation Mission. (2019). Final Report on Presidential elections 21 April and 5 May 2018 FYROM, Warsaw: OSCE/ODIHR

12. OSCE/ODIHR Referendum Observation Mission. (2019a). Final Report on Referendum 30 September 2018 FYROM, Warsaw: OSCE/ODIHR

13. OSCE/ODIHR Election Observation Mission. (2018). Final Report on Municipal elections 15 October and 29 October 2017 FYROM, Warsaw: OSCE/ODIHR

14. OSCE/ODIHR Election Observation Mission. (2017). Final Report on Early parliamentary elections 11 December 2016 FYROM, Warsaw: OSCE/ODIHR

15. OSCE/ODIHR Election Observation Mission. (2017a). Statement of Preliminary Findings and Conclusions on Municipal Elections, Second round 29 October 2017 FYROM, Warsaw: OSCE/ODIHR

16. OSCE. (1990). Document of the Copenhagen Meeting of the Conference on the Human Dimension of the CSCE

17. Ristikj, J. (2019). Legal Protection of Voting Rights, Skopje: Institute for Legal and Political Research

18. Roagna, I. (2012). Protecting the right to respect for private and family life under the European Convention on Human Rights, Strasbourg: Council of Europe

19. State Election Commission. (2019). Report on the Elections for President of the Republic of North Macedonia held on April 21 and May 5, 2019, Skopje: State Election Commission

20. State Election Commission. (2019a). Notification 03/1808/2 from 03.07.2019 to the Institute for Legal and Political Research (https://ippi.mk/), Skopje: State Election Commission

21. State Election Commission. (2019b). Notification 03/1808/3 from 03.07.2019 to the Institute for Legal and Political Research (https://ippi.mk/), Skopje: State Election Commission

22. State Election Commission. (2018). Notification 03-2449/9 from 14.11.2018 to the Institute for Legal and Political Research (https://ippi.mk/), Skopje: State Election Commission 
23. State Election Commission. (2018a). Notification 03-2449/7 from 14.11.2018 to the Institute for Legal and Political Research (https://ippi.mk/), Skopje: State Election Commission

24. State Election Commission. (2018b). Notification 03-2449/8 from 14.11.2018 to the Institute for Legal and Political Research (https://ippi.mk/), Skopje: State Election Commission

25. State Election Commission. (2017). Notification 03-2961/2 from 07.12.2017 to the Institute for Legal and Political Research (https://ippi.mk/), Skopje: State Election Commission

26. State Election Commission. (2017a). Notification 03-2961/2 from 07.12.2017 to the Institute for Legal and Political Research (https://ippi.mk/), Skopje: State Election Commission

27. United Nations. (1948). Universal Declaration of Human Rights, United Nations, Treaty Series, 217 A (III)

28. United Nations. (1966). International Covenant on Civil and Political Rights, United Nations, Treaty Series, vol. 999

29. United Nations. (2007). Convention on the Rights of Persons with Disabilities: resolution/adopted by the General Assembly, United Nations, A/RES/61/106 